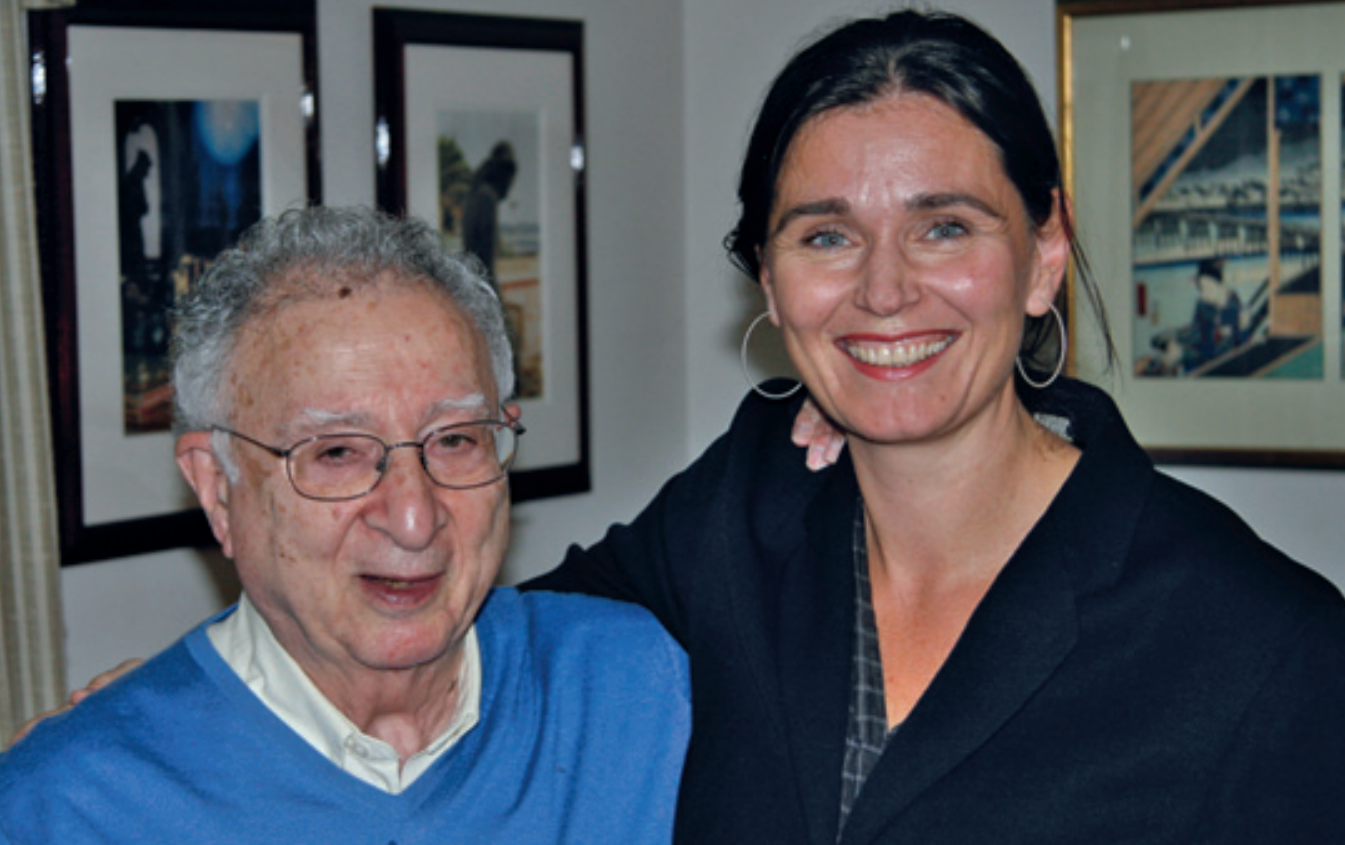

Marvin Zelen og Mette Kalager. Foto privat

\title{
Mammografi har liten effekt
}

\author{
Brystkreftdødeligheten er redusert med kun 10\% ti år etter innføring \\ av det norske Mammografiprogrammet. Det viser en norsk studie \\ i New England Journal of Medicine.
}

Hensikten med studien var å evaluere det norske Mammografiprogrammet (1). Grunnet den trinnvise introduksjonen av programmet i fylkene, var det mulig å etablere en kontrollgruppe av kvinner som ikke var invitert til mammografiscreening i samme tidsrom som Mammografiprogrammet har pågått (ikke-screeninggruppe). Disse kvinnene bodde i fylker som ikke hadde startet med Mammografiprogrammet, og ble sammenliknet med kvinner som bodde i fylker der dette var etablert (screeninggruppe). Ved å sammenlikne disse to gruppene unngikk forskerne konfundering av faktorer som forbedret behandling og den økte bevisstheten rundt brystkreftsykdommen som endres over tid og er assosiert med redusert brystkreftdødelighet. Det ble også etablert to historiske kontrollgrupper som imiterte introduksjonen av Mammografiprogrammet i fylkene i tiårsperioden før programmet startet opp. Studien omfattet 40075 kvinner.

Blant kvinner i screeningalder (50-69 år) fant man en reduksjon i brystkreftdødelighetsraten (mortalitetsrateratio, MRR) på $18 \%$ for ikke-screeninggruppen (MRR 0,82; $95 \%$ KI $0,71-0,93, \mathrm{p}<0,001)$, og $28 \%$ for screeninggruppen (MRR 0,72; $95 \%$ KI 0,63-0,81, p <0,001), sammenliknet med de respektive historiske gruppene. Dette gir $10 \%$ reduksjon i brystkreftdødelighet som kan tilskrives Mammografiprogrammet $(\mathrm{p}=0,13)$. Den tilsvarende dødelighetsreduksjonen for kvinner i alderen 70-84 år (som ikke er invitert til screening) var nesten like stor $(8 \%, \mathrm{p}=0,09)$.

- Designet med fire studiegrupper gjør at vi kan skille den rene dødelighetseffekten av mammografiscreening fra bedret behandling og økt bevissthet rundt brystkreft, faktorer som også reduserer dødeligheten, sier førsteforfatter Mette Kalager.

- Da Mammografiprogrammet ble innført, var det forventet at brystkreftdødeligheten skulle reduseres med $30 \%$ etter ti år. Men denne studien viser at kun en tredel, altså $10 \%$, av reduksjonen i brystkreftdødelighet etter introduksjon av Mammografiprogrammet kan tilskrives programmet og at dødeligheten er nesten like stor for eldre kvinner som behandles ved brystdiagnostiske sentre. Myndighetene bør nå revurdere nytten av Mammografiprogrammet i lys av denne studien, sier Kalager.

\section{Forskning på brystkreftscreening}

Forskere ved Kreftregisteret samarbeider med forskere ved Harvard School of Public Health. Mette Kalager har vært Leiv Eiriksson-stipendiat ved Harvard School of Public Health og er nå forsker samme sted. Hans-Olov Adami, som er leder av Avdeling for epidemiologi og professor ved Avdeling for biostatistikk Marvin Zelen er sentrale i gruppen. Gruppen samarbeider om forskning på brystkreft i relasjon til brystkreftscreening og drar nytte av gode brystkreftdata i Norge samt epidemiologisk og biostatistisk høykompetanse i Boston.

\section{Erlend Hem}

erlend.hem@medisin.uio.no

Tidsskriftet

\section{Litteratur}

1. Kalager M, Zelen M, Langmark F et al. Effect of breast-cancer screening on mortality in Norway. N Engl J Med 2010; 363: 1203-10.

\section{Ordforklaringer}

\section{Mammografiprogrammet startet opp} i fire fylker i 1995-96. Utbredelsen av programmet skjedde trinnvis, og i løpet av 2005 ble alle kvinner i alderen 50-69 år invitert til mammografiundersøkelse hvert annet år.

Brystdiagnostiske sentre: Et av kriteriene for at fylkene ble innlemmet i Mammografiprogrammet var at de omorganiserte diagnostikk og behandling av brystkreftpasientene. Brystdiagnostiske sentre ble opprettet på sykehusene, og ukentlige, tverrfaglige møter mellom diagnostikere og behandlere av brystkreftpasienter ble innført. Reorganiseringen av diagnostikk og behandling av brystkreft vil ikke bare komme kvinnene som inviteres til Mammografiprogrammet til gode, men alle kvinner som diagnostiseres og behandles på disse sykehusene (1).

\section{Litteratur}

1. Kalager M. Bedre behandling ved brystdiagnostiske sentre. Tidsskr Nor Legeforen 2009 129: 1614.

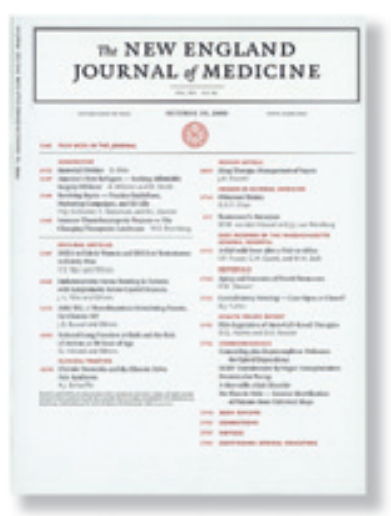

Artikkelen ble publisert 23.9. 2010 i New England Journal of Medicine (www.nejm.org), som er verdens høyest rangerte generelle medisinske tidsskrift. (c) The New England Journal of Medicine, 2006

\section{Tips oss}

Er du i ferd med å publisere eller har du nylig publisert eller har du nylig publisert Send tips til Send tips til www.tidsskriftet.no/ norskforskning 